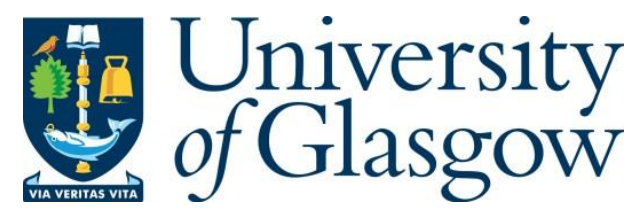

Gherghina, S. and Silagadze, N. (2020) Populists and referendums in Europe: dispelling the myth. Political Quarterly, 91(4), pp. 795-805.

There may be differences between this version and the published version. You are advised to consult the publisher's version if you wish to cite from it.

$\underline{\text { http://eprints.gla.ac.uk/225772/ }}$

Deposited on: 2 November 2020

Enlighten - Research publications by members of the University of Glasgow http://eprints.gla.ac.uk 


\title{
Populists and Referendums in Europe: Dispelling the Myth
}

Sergiu Gherghina

Department of Politics

University of Glasgow

Adam Smith Building

40 Bute Gardens, G128RT, Glasgow, UK

Nanuli Silagadze

Department of Political Science

Abo Akademi Finland

Samforsk, ASA A4, 20500 Åbo, Finland

\begin{abstract}
Many researchers, journalists and politicians are inclined to connect populism and referendums. While in theory the two rest on similar principles, in practice this is not the case. This article shows that populist political elites make limited use of referendums compared both to their rhetoric and to non-populists. Our findings indicate that the use of referendums is not a reflection of populist politics. They also illustrate how populists may initiate referendums strategically and they win them quite often. The analysis draws on all 64 national level referendums initiated by political elites between 2000 and 2019 in Europe.
\end{abstract}

Keywords: populists, referendums, binding, approval, Europe

\section{Introduction}

Both populism and referendums are established features of the European political system in the last two decades. Populism is reflected by the regular electoral success of of political leaders such as Silvio Berlusconi, Viktor Orbán or Alexis Tsipras. It is also illustrated by the persistent parliamentary presence of political parties considered to be populist - both to the left and to the right of the political spectrum - throughout the continent. Contemporary referendums tend to be held as a vehicle to decide major policy issues Given the prominence of populism and referendums, it is tempting to connect them. This happens especially in the light of recent referendums such as those related to the change of the constitution (Turkey 2017), Brexit (UK 2016), austerity measures (Greece 2015) or anti-EU migration policies (Hungary 2016). 
From an ideational perspective, referendums are a good fit for populism. They are people-centred, they can bypass the representative channels of decision-making process and they challenge the position of political elites by providing possibilities for vertical accountability between elections. The party programmes and election manifestos of several populist parties explicitly demand referendums, e.g. Alternative for Germany, Danish People's Party, Finns Party, Freedom Party of Austria, National Rally in France etc. Referendums are particularly appealing to small populist, anti-establishment, and protest parties both on the right and left spectrum because they have little to lose. Moreover, referendums can be and are used (see the examples above) to address complex issues with a simple yes / no vote. This approach is in line to the populist idea of simple solutions to complicated matters.

However, the perceived relationship between populism and referendums and the theoretical arguments about such a relationship are not reflected in practice. This article shows that populist political parties and politicians do not make extensive use of referendums. It reveals that the association between the two is more the result of cherry-picking rather than of systematic analysis. The evidence indicates that the increasing use of referendums is not a reflection of populist politics. On the contrary, populists make limited use of referendums compared to their rhetoric. The article also illustrates that populists win three quarters of the referendums they initiate. We use evidence from all 64 national level referendums initiated by political elites between 2000 and 2019 in Europe. Our study contributes to the existing research on populism and referendums in two ways. First, it addresses a gap in the literature by focusing on the actual use of referendums by populists. So far, scholarly attention has been directed mainly at the relationship between populist attitudes of citizens and their support for referendums. Second, it illustrates that the relationship between the two is not as straightforward as theorised so far; the practice is nuanced and require further investigation. This is the first study to provide comparative results that go beyond single case studies and context sensitive findings.

The following section discusses the relationship between populism referendums, as covered in the literature. The second section outlines the methodology and data used for our analysis. The third section provides empirical evidence and compares the use of referendums by populist and non-populist political actors. The conclusions summarise the key findings and discuss the broader implications of this analysis for the study of populism and referendums. 


\section{Linking populism and referendums}

The literature proposes three main approaches to populism: ideational, strategic and discursive. These categories are not mutually exclusive and there is evidence of crossover as ideational-strategic or discursive-strategic. The ideational perspective is the most relevant to this study because it has been the one linked with referendums. The most commonly used definition of populism is "an ideology that considers society to be ultimately separated into two homogeneous and antagonistic groups, 'the pure people' versus the 'corrupt elite,' and which argues that politics should be an expression of the volonté générale (general will) of the people". ${ }^{1}$ There are four core elements of populist rhetoric: the central position of the people, critique of the elite, perception of the people as a uniform entity, and the proclamation of a serious crisis. ${ }^{2}$ Looking at these features, there is a match between populism and referendums because the latter are people-centred, reduce the power of the elite and provide a possibility for accountability.

The association between populism and referendums goes back to the early days of populism. The American Populist Party and its allies fought successfully to establish direct democracy at the end of the $19^{\text {th }}$ century in the American states as a means to alter the political status. ${ }^{3}$ The literature on populist parties explicitly argues that they consider referendums as a normatively superior form of decision-making and express support in their programmes for direct democracy, in general, and for referendums, in particular. ${ }^{4}$ By and large, it is no surprise that populists favour referendums since they can be viewed as a way to give power back to the people. The referendums offer voters the right to decide directly on important policies, thus bypassing the normal channels of representative politics.

Populists in European democracies have been traditionally right-wing. Only in the last decade left-wing populist parties emerged and gained electoral weight, e.g. Podemos in Spain, SYRIZA in Greece. The key element that distinguishes right-wing populism from other forms is its racial and ethnic component - they are nativists and claim to represent the true people who make up the true nation; the concerns about immigration is their brand mark. For leftwing populists, the enemy is neoliberalism. The common denominators of many populist parties across the political spectrum is their preference for referendums. The latter are seen as the solution for the failures of democratic governments to deliver results that are in line with what 'the people' want. Right-wing populist parties present themselves as the 'real' democrats combining critiques of how liberal democracy functions with calls for referendums 
to give the people greater voice. This support for more direct forms of democracy is one of the distinguishing features of contemporary populist radical right from previous groups of the extreme right. ${ }^{5}$ For some populists, their ideological flexibility combined with the emphasis on referendums has served as a winning formula. This is the case of the Five-Star Movement in Italy for which 'the meta-discourse about direct democracy constitutes the main ('thin') pillar of the party's discourse and acts as a glue for both left-wing and right-wing voters. ${ }^{6}$

To date, research linking populism and referendums focused extensively on people's attitudes. The studies investigate whether citizens with populist attitudes consider referendums as a more legitimate way of decision-making. This is based on the essential belief of populists according to which people should be their own rulers, while political elites stand in the way of government by the people. There is mixed evidence about this relationship. For instance, a comparative study that covers left and right-wing populist parties in Belgium, Germany and the Netherlands concludes that dissatisfaction with democracy, a desire for direct decision making and voting for right-wing populist parties go together. ${ }^{7}$ In contrast, the analysis of citizens voting for right-wing populist parties in Australia, Canada and New Zealand shows no correlation between voting for populists and support for direct democracy. ${ }^{8}$ Another study about citizens' attitudes in the Netherlands shows that people who possess populist attitudes are in favour of referendums but they are not willing to vote in them. ${ }^{9}$

There is increasing research about how referendums are instrumentalised by political parties. ${ }^{10}$ However, there is little agreement about the way in which populists use referendums. One perspective suggests that referendums have become a powerful instrument that helps populist parties to mobilise those who feel unrepresented. As such, it serves as a tool to promote their profile and the scope of their political influence by harvesting the resentment against the elites. Referendums can be seen as a one-off event that is decoupled from cyclical accountability as it is the case with elections. Consequently, populists, as marginal players, have little to lose from misrepresenting preferences and policy goals in referendums. ${ }^{11}$ An opposing viewpoint postulates that most referendums have not been launched by populists in an attempt to overturn the status quo, but were rather mandated by national constitutions. ${ }^{12}$ Referendums in the democratic countries led to the recent growth in the number of direct popular votes. In Europe, more than $70 \%$ of all national level referendums were conducted in democracies. ${ }^{13}$ 
This literature review indicates that populism and referendums can be linked in several ways. Very often, the arguments are theoretical and they have their origin in the ideational core of populism and in the purposes of referendums. When it comes to practice, earlier research presents a nuanced picture. Populists often remain silent about referendums and fail to follow through on their promises for more 'direct democracy' once they enter government or constitute the governing majority. ${ }^{14}$ Moreover, when populists lose the referendums they initiate, they tend to ignore the outcome or blame the others for it. ${ }^{15}$ Our study enriches this picture by comparing the use of referendums by populist and non-populist actors over time. The following section briefly explains the methodology and data that we use to achieve this goal.

\section{Methodology and Data}

Our analysis uses evidence from all top-down referendums organised at national level in Europe between 2000 and 2019. Our original dataset covers 64 referendums initiated by political elites in 25 countries (for a complete list, see Appendix). Switzerland is excluded from the analysis since nearly equal number of referendums was held there as in the remaining countries together and would have distorted the findings. We did not include the citizendriven referendums because it is difficult to establish a connection with the political actors. Thus, even if populist actors were behind citizens' initiatives leading to referendums, the role and importance of populists is difficult to establish in most cases. All mandatory referendums were also excluded from the analysis because in their case the decision to call for a referendum is not taken by political actors.

Our analysis rests on a comparison between the referendums initiated by populist and non-populist political actors. The latter includes both politicians - when the referendum is called by the head of state - and political parties. We label as populist initiators all those political actors that match the definitions of populism used in the literature and outlined in the previous section. To determine whether the initiator is populist we used multiple sources of information: academic texts, newspaper articles, country reports and analyses. If several parties initiated a referendum and one of them is a populist, we count that referendum as being initiated by populists. This decision rests on the idea that populists have a direct connection with that specific referendum and for procedural or strategic reasons they join 
forces with other initiators. According to this criterion there are 16 referendums initiated by populists and 48 that are initiated by non-populists (see Appendix 1).

We conduct several types of analyses meant to capture the differences between referendums initiated by populists and non-populists. First, we run a comparison over time for the frequency of referendum use. Second, we analyse if populists win the referendums they initiate. Wining means that the votes cast in favour of the initiator's preferences is in majority and the referendum meets the required threshold conditions in the country. The adoption rules vary across political systems. Some countries require no participation quorum to validate the results and a majority of votes expressed in favour of the proposal means it is won. Other countries require a participation threshold to validate the popular vote. Our coding accounts for these legislative details. We code 0 for the lost votes and 1 for the votes won. For example, the initiator of the 2016 referendum in Hungary went for a "no" vote, the "no" votes were in majority but the turnout was below the required participation quorum for validation. Consequently, the initiator was defeated and this is coded 0.

Third, we look at the status of the referendum and we differentiate between binding (coded as 1 ) and non-binding (coded as 0 ). Fourth, we compare the popularity of referendums among citizens. To establish the popularity, we calculate the approval rates relative to turnout and to the intention of the initiator in each referendum. We multiply the votes in favour of the proposal as intended by the initiator with the turnout and we divide it by 100 to obtain the approval rates in the entire electorate. In the vast majority of cases, we look at the 'Yes' votes. For example, the French referendum organised in 2000 to reduce the presidential term in office from 7 years to 5 years has a turnout of $30.19 \%$ out of which $73.21 \%$ voted in favour of this proposal. The popularity of this referendum - or the approval rate in the entire society - is $22.10 \%$.

Fifth, we seek to identify whether populists call for referendums in new or established democracies. To this end, we calculate the age of democracy for the countries in which referendums are called by populists and non-populists. The age of democracy was defined on the basis of Freedom House reports. The 'free status' is used as a proxy for democracy. If the democratic rule is interrupted and restored, the age of democracy is counted since the restoration of the democratic rule. Finally, we look at the policy area of referendums to understand the extent to which populists target key areas in society. 


\section{Limited use of referendums and strategic behaviour}

The discussion about the data provides an important piece of evidence. In the last two decades the populists have initiated one quarter of the national level referendums in Europe. The number of referendums called by populists does not increase over time. On the contrary, in the last decade (2010-2019) there are considerably fewer referendums called by populists compared to the previous decade. Figure 1 shows that the majority of referendums called by populists took place between 2000 and 2009. In this time interval they called for roughly two thirds of their total number of referendums. This coincides with the breakthrough of populist parties in the political systems of several European countries. According to this trend, the populists appeared to be more oriented towards calling referendums in the early days of their access to the political establishment. Once they have become accustomed with the system of representative democracy, they called fewer referendums. The trend for the referendums initiated by non-populists goes in the opposite direction. They make more use of referendums in the 2010-2019 decade, when they call roughly $60 \%$ of their referendums. Consequently, one cannot argue that populists call for fewer referendums in the last decade because there are fewer referendums organised overall. In essence, there are considerably fewer referendums called by populists in recent times both in absolute numbers and relative to the total number of referendums called in Europe. 
Figure 1: The distribution of referendums according to their initiator

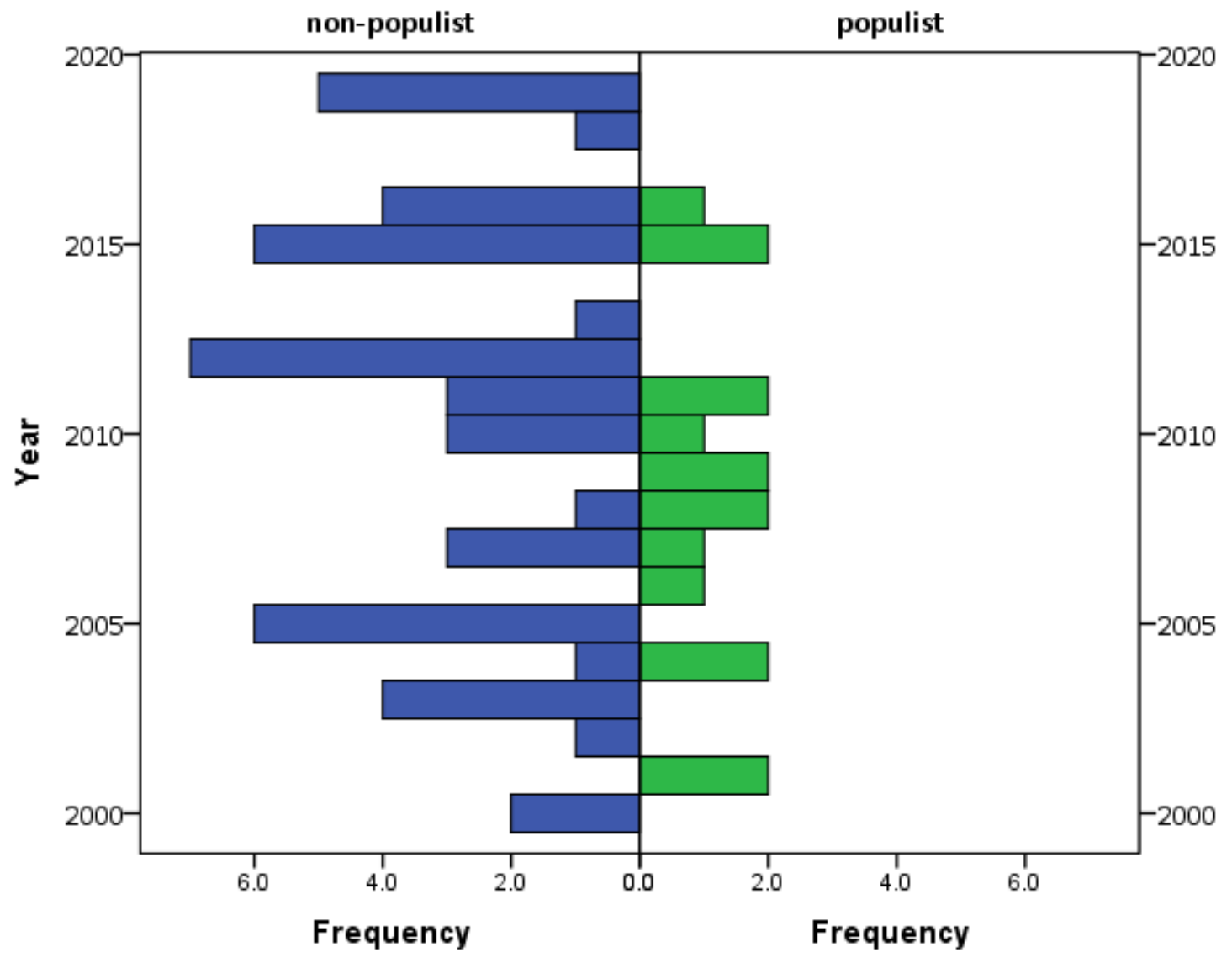

These numbers illustrate a mismatch between populists' declared appetite for referendums and reality. One explanation for which populists fail to practice what they preach is that populism is characterised by a centralisation of power around the leader. The claimed affinity for referendums serves mainly as a strategic ploy. ${ }^{16}$ Once populists represent the governing majority, the function of the referendum transforms and becomes a tool for centralising power in the hands of the leader. ${ }^{17}$ Disparity between what populists say and do is summarised best as: 'Ideational notions highlight the progressive, direct-democratic rhetoric and façade but overlook the essence of populism, which revolves around top-down leadership'. ${ }^{18}$

Next, we compare the share of referendums won by populist and non-populist initiators. Our analysis includes the referendums won by each type of initiator. It does not discuss the referendums in which populists were actively engaged in campaigning. We calculate the percentage of won referendums from the total number of referendums called by each type of initiators. The results indicate that populists win considerably more popular 
votes compared to non-populists. The populists have won three quarters $(75 \%)$ of the referendums that they initiate. Non-populist initiators win slightly more than half (55\%) of the referendums that they initiate. These results indicate that in most cases in which populists push for policies through referendums, they stand a good chance of winning the popular vote. We know from the theory and practice of referendums that there is no guarantee of the vote going the way intended by the initiators. It appears that populists resort to referendums when they stand a good chance of winning it. A good chance of winning occurs when the referendum addresses a contested issue in society or when the referendum opposes actions of mainstream parties that are contested, e.g. the 2001 referendum in Slovenia about artificial insemination for unmarried women.

An important difference can be observed in terms of the status of referendums that are initiated. Figure 2 illustrates the percentages of binding (dark grey) and non-binding (light grey) referendums called by both types of initiators. The populists prefer binding over nonbinding referendums. This approach is consistent with their desire to give voice to the people and to circumvent institutions of representative democracy. This happens effectively if the decisions reached by the electorate are implemented directly by the institutions. The populists use non-binding referendums to a less extent because they do not guarantee the implementation of popular will. These can even strengthen the position of representative institutions, by giving them - at least in theory - a veto right. The non-populist initiators have the opposite approach and they call non-binding referendums much more frequently $(60 \%)$. They appear to use the referendums more to learn about citizens' opinions on various policies. In practice, many non-binding referendums are often implemented because the state institutions do not go against the public's views and vote.

Figure 2: The distribution of referendums according to their binding status 


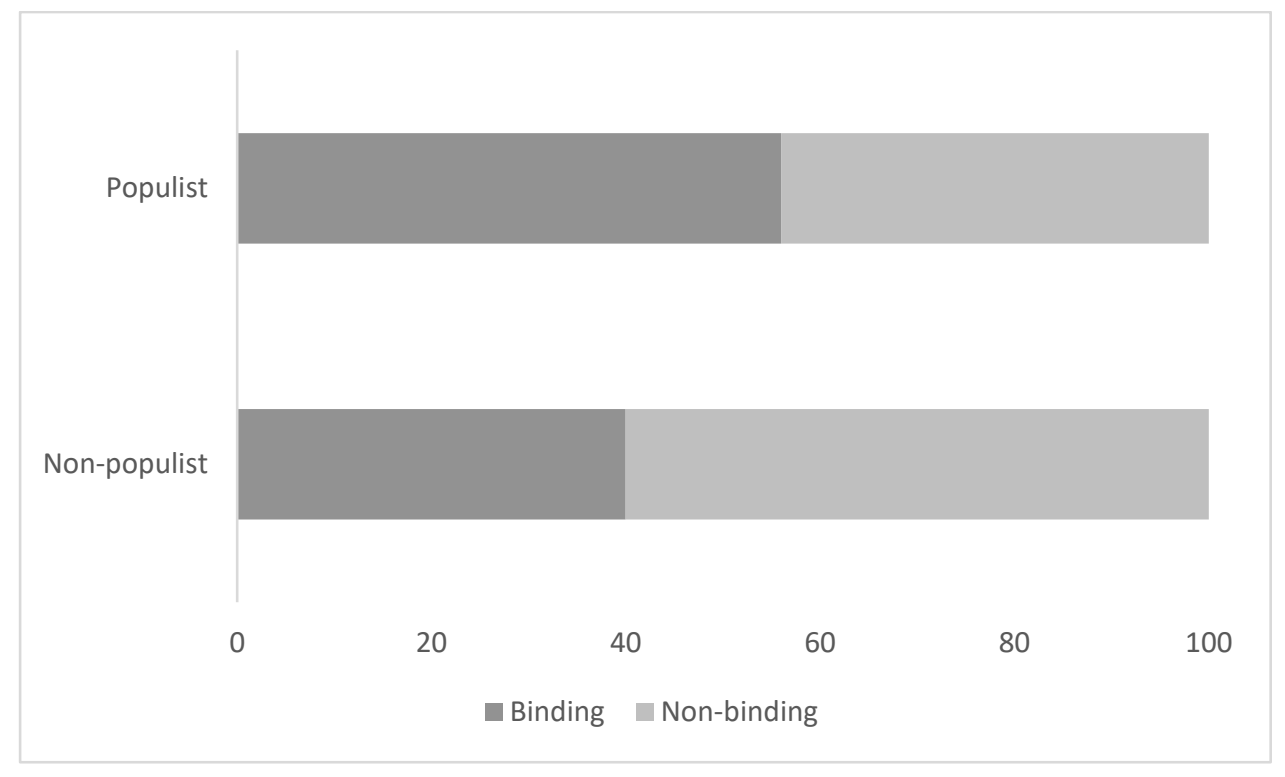

We checked the association between winning the referendum and the status for each type of initiator. The results indicate that although populists have a tendency to initiate more binding referendums, they win fewer of these compared to the non-binding referendums that they initiate. Out of the total of nine binding referendums initiated by populists, they won six. Out of a total of seven non-binding referendums initiated by populists, they won six, which is the equivalent of $86 \%$. The non-populists win $62 \%$ out of the non-binding referendums and $42 \%$ of the binding referendums. These observations are confirmed also by the values of the association coefficients (Phi Cramer's V), which are -0.22 for populist initiators and -0.20 for non-populist initiators. The negative sign of the coefficient reflects that non-binding referendums are won more than the binding ones, see the coding in the previous section. Overall, these percentages and association coefficients indicate that populists are somewhat greater chances to win a popular vote when this is not binding. At the same time, populist initiators have a considerably higher rate of won binding referendums compared to nonpopulist initiators.

So far, this article has discussed the approaches of initiators towards referendums. We would like to see how popular these referendums are among the electorate of a country. Figure 3 depicts the distribution of approval rates in society calculated as percentages of votes among the electorate cast in favour of the policy in referendums. The dark grey bars are the referendums initiated by populists and the light grey bars are the referendums initiated by non-populists. The distribution indicates that the approval rates for populist referendums are divided in three groups: low (up to roughly 10\%), medium (around $25 \%$ ) or high (above $40 \%$ ) 
in the electorate. One example of low support is the 2001 Italian referendum on greater legislative powers to the regions. The draft legislation proposed by the centre-left government was criticised by the centre-right opposition and the populist Northern League, which called for a referendum. The results backed the government proposal with a minimum support (roughly $12 \%$ in the electorate) for the initiators. The 2008 double referendum in Georgia is an example of high popular support. This was determined by protests in the previous year, which led to violence from police, the call for a state of emergency and early presidential elections. The incumbent country president called for a double non-binding referendum on whether to have early parliamentary elections and Georgia should join NATO. The incumbent was re-elected and both questions were approved by wide margin (almost $80 \%$ ) with relatively high turnout (56\%).

The referendums initiated by non-populists present a more nuanced view. They have a broad variety of approval rates in the electorate (Figure 3). Some of the referendums are met with opposition by the electorate, while others are quite popular. One example for the low popularity is 2010 Icelandic referendum on Icesave repayment bill. Iceland's parliament passed narrowly an Icesave bill that guaranteed to repay British and Dutch governments around $\$ 5$ billion for deposits lost after the online bank failed. The deal was highly unpopular among the citizens who collected signatures to ask the president not to sign the bill. The president vetoed the bill and sent it for approval to a referendum in which more than $98 \%$ of citizens voted against the repayment bill. In contrast, the 2005 referendum on the EU Constitution in Luxembourg enjoyed high popularity. The high importance of the issue determined Prime Minister Juncker to hold an advisory referendum in which he declared to resign in case of a "No" vote. More than $56 \%$ of citizens approved the European Constitution with a very high turnout (roughly 90\%) mainly due to the compulsory voting.

Figure 3: The distribution of referendums according to approval rates in society 


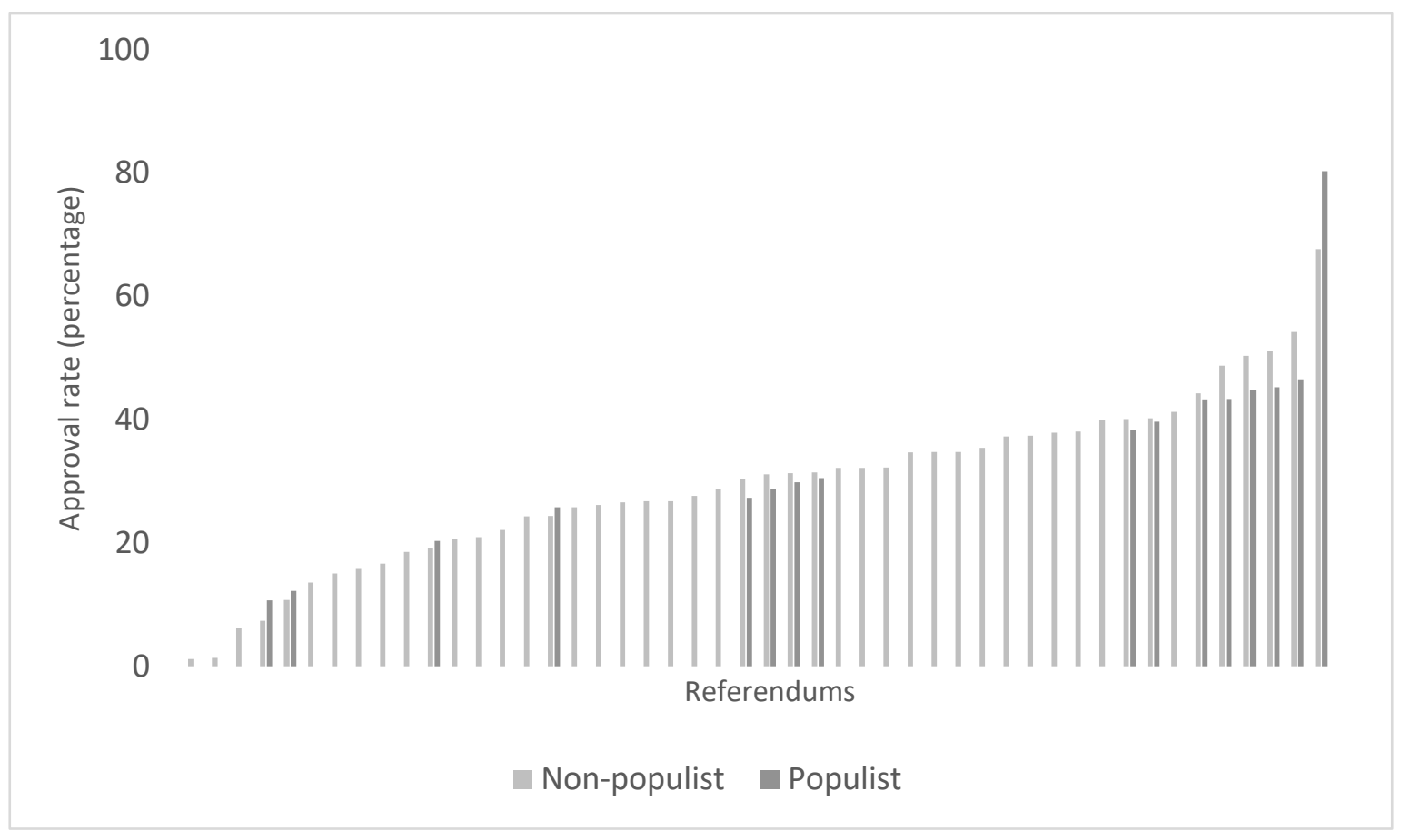

The final two factors that we analyse are the context in which populists call for referendums and on what topics. To start with the context, our analysis indicates that populists initiate more referendums in authoritarian regimes, transition countries or new democracies. They are less active in established democracies. The average age of democracy in countries where populists initiate referendums is 20 years. In contrast, the non-populist initiate referendums in established democracies: average age of democracy 50 years. One possible explanation for this discrepancy is the desire of populists to replace representative democracy with direct democracy. Such a process is more likely to occur in countries where the institutions of representative democracy are not well established.

In terms of topics on which referendums are organised, there is no visible difference between populist and non-populist initiators. They both focus extensively on five policy areas: constitution making, state formation, political and electoral system, interior policies and foreign affairs. Populists call more than three quarters of their referendums on these policy areas, while non-populists initiate two thirds of their referendums on the same topics. The most popular area for populists is that of the political and electoral system on which they call almost half $(43 \%)$ of the total number of referendums. This is in line with their desire to reorganise society and politics along different principles. For non-populists, the same policy area is appealing, with roughly one quarter of their referendums being called on it (27\%). This is followed by foreign affairs with $21 \%$ and economy with $15 \%$. Populists and non-populists 
initiate similar numbers of referendums on post-materialist values. The importance of these issues is relatively marginal for the two types of initiators. The populists call for $19 \%$ of their referendums on issues such as moral and ethics or media freedom, while the non-populists roughly $12 \%$.

\section{Conclusions}

This article aimed to illustrate that the association between populism and referendums is more the result of cherry-picking rather than of systematic approach. It brings empirical evidence from all elite-initiated referendums in Europe between 2000 and 2019 to make several points. Populists initiate considerably fewer referendums than non-populists and their use of referendums has decreased over time. For non-populists, the trend is reversed: they make more extensive use of referendums in the most recent decade. Usually populists initiate referendums in authoritarian regimes, transition countries or new democracies, while the non-populists initiate more referendums in established democracies. This trend may be telling for the context in which populists seek to give voice to the people through referendums. It is relevant to note that populists win a larger share of the referendums that they initiate compared to non-populists. This can mean several things. One of them is that populists use strategically referendums when they stand a good chance of winning them. In doing so, their image of referendum promoters is associated with a positive outcome. Another possibility is that populists initiate referendums on issues that are sufficiently salient to mobilise a majority that backs their point of view.

The populists have a preference for binding over non-binding referendums, but this may not always be a winning card. According to the evidence that we present, they win nonbinding referendums to a greater extent than binding. The policies subjected by policies to referendums have either limited or major traction within the population. If the referendum falls in the first category, there are very limited chances for success. There is great similarity in terms of policies subjected by populists and non-populists to referendums. Both types of political actors give priority to domestic policies with a high emphasis on issues related to the political and electoral system.

Despite the encouraging record of referendums won, populists do not make extensive use of this tool. This happens although referendums are used increasingly throughout the world, which indicates that such a trend cannot be attributed mainly to the presence of 
populists in the political systems. In the last two decades political elites have used referendums at national level with policy (e.g. set the agenda, increase the popularity or legitimacy of decisions) or institutional goals (e.g. avoiding deadlocks, bypassing the conventional decision-making processes or solving intra-party conflicts) in mind. ${ }^{19}$ None of these goals is specific to populists. Moreover, statistically speaking, the likelihood for populists to call referendums is smaller. Although there is at least one populist party in each country covered by our analysis, the number of non-populists is considerably higher in every party system. To understand how and why populists call referendums, further research can approach the topic through the lenses of features that differentiate populists from other political actors. For example, the populist conception of 'the people' can be a reason for which they push for a collective expression of will. Along these lines, referendums can provide the opportunity for populist parties to be one and the same voice with the people they claim to represent.

\section{Acknowledgements}

The authors are grateful to Michael Scanlan for his careful reading, excellent suggestions and constructive criticism on earlier versions of this article. 
Appendix 1: The list of referendums included in analysis

\begin{tabular}{|c|c|c|c|}
\hline Country & Year & Topic & Initiator \\
\hline France & 2000 & Reduction of presidential term of office & Non-populist \\
\hline Liechtenstein & 2000 & Facilitated naturalization for long-time residents & Non-populist \\
\hline Italy & 2001 & Greater legislative powers to the regions & Populist \\
\hline Slovenia & 2001 & Artificial insemination for unmarried women & Populist \\
\hline Liechtenstein & 2002 & Spatial planning law & Non-populist \\
\hline Malta & 2003 & EU membership & Non-populist \\
\hline Slovenia & 2003 & EU membership & Non-populist \\
\hline Slovenia & 2003 & NATO membership & Non-populist \\
\hline Sweden & 2003 & Introduction of Euro & Non-populist \\
\hline Belarus & 2004 & Unlimited re-eligibility of the president & Populist \\
\hline Cyprus & 2004 & Foundation of a Reunified Republic of Cyprus & Non-populist \\
\hline Slovenia & 2004 & On minority rights & Populist \\
\hline France & 2005 & European Constitution & Non-populist \\
\hline Liechtenstein & 2005 & Abortion & Non-populist \\
\hline Luxembourg & 2005 & European Constitution & Non-populist \\
\hline Netherlands & 2005 & European Constitution & Non-populist \\
\hline Slovenia & 2005 & Regulation of the Slovenian public broadcaster & Non-populist \\
\hline Spain & 2005 & EU Constitution & Non-populist \\
\hline Italy & 2006 & Constitutional reform & Populist \\
\hline Portugal & 2007 & Legalizing abortion & Non-populist \\
\hline Romania & 2007 & On electoral system (majority vote) & Populist \\
\hline Slovenia & 2007 & Act on Transfer of Ownership of Insurances & Non-populist \\
\hline Turkey & 2007 & Constitutional reform & Non-populist \\
\hline Georgia & 2008 & Early parliamentary elections & Populist \\
\hline Georgia & 2008 & NATO membership & Populist \\
\hline Lithuania & 2008 & Extending the operation of the Ignalina nuclear power plant & Non-populist \\
\hline Romania & 2009 & Introducing unicameral parliament & Populist \\
\hline Romania & 2009 & Reducing the number of parliamentarians to maximum 300 & Populist \\
\hline Iceland & 2010 & Icesave repayment bill & Non-populist \\
\hline Moldova & 2010 & Direct election of the president & Non-populist \\
\hline Slovenia & 2010 & Border dispute agreement with Croatia & Non-populist \\
\hline Slovenia & 2010 & Law of the Slovenian public broadcaster & Populist \\
\hline Iceland & 2011 & Icesave repayment bill & Non-populist \\
\hline Malta & 2011 & Divorce for separated couples & Non-populist \\
\hline Slovenia & 2011 & Law on document protection and archives & Populist \\
\hline Slovenia & 2011 & Law against illicit work & Populist \\
\hline United Kingdom & 2011 & Alternative Vote electoral system & Non-populist \\
\hline Iceland & 2012 & Draft of the Constitutional Commission & Non-populist \\
\hline Iceland & 2012 & Election of particular individuals to the parliament & Non-populist \\
\hline Iceland & 2012 & Equal weight for each vote & Non-populist \\
\hline Iceland & 2012 & Introduction of initiatives & Non-populist \\
\hline Iceland & 2012 & Provisions on the position of the state church & Non-populist \\
\hline
\end{tabular}




\begin{tabular}{|l|l|l|l|}
\hline Iceland & 2012 & Public ownership of natural resources & Non-populist \\
\hline Lithuania & 2012 & Construction of a new nuclear power station & Non-populist \\
\hline Austria & 2013 & Future of the army & Non-populist \\
\hline Bulgaria & 2015 & Introduction of electronic voting & Populist \\
\hline Greece & 2015 & On accepting bailout conditions & Populist \\
\hline Luxembourg & 2015 & Lowering voting age from 18 to 16 & Non-populist \\
\hline Luxembourg & 2015 & Voting right for foreign residents & Non-populist \\
\hline Luxembourg & 2015 & Term limits for ministers & Non-populist \\
\hline Poland & 2015 & Single-member constituencies for parliamentary elections & Non-populist \\
\hline Poland & 2015 & Maintaining state financing of political parties & Non-populist \\
\hline Poland & 2015 & Presumption in favour of the taxpayer & Non-populist \\
\hline Hungary & 2016 & EU migrant quota & Populist \\
\hline Italy & 2016 & Constitutional reform & Non-populist \\
\hline Italy & 2016 & Oil and natural gas drilling & Non-populist \\
\hline Liechtenstein & 2016 & Family allowance law & Non-populist \\
\hline United Kingdom & 2016 & EU membership & Non-populist \\
\hline Macedonia & 2018 & Changing name to North Macedonia & Non-populist \\
\hline Liechtenstein & 2019 & Financing a new public hospital & Non-populist \\
\hline Moldova & 2019 & Reducing the number of MPs from 101 to 61 & Non-populist \\
\hline Moldova & 2019 & Introducing the right to recall MPs & Non-populist \\
\hline Romania & 2019 & Prohibiting amnesties and pardons for corruption offences & Non-populist \\
\hline Romania & 2019 & $\begin{array}{l}\text { Prohibiting the Government from passing emergency } \\
\text { ordinances }\end{array}$ & Non-populist \\
\hline & & & \\
\hline
\end{tabular}

\section{Notes}

${ }^{1}$ C. Mudde, 'The Populist Zeitgeist', Government and Opposition, 39/4 (2004): 544.

2 M. Rooduijn, 'The nucleus of populism: In search of the lowest common denominator', Government and Opposition, 49/4 (2014): 572-598.

${ }^{3}$ S. Piott, Giving Voters a Voice: The Origin of the Initiative and Referendum in America. Columbia, MO: University of Missouri Press, 2004.

${ }^{4}$ P. Taggart, Populism. Buckingham: Open University Press, 2000.

${ }^{5}$ D. Albertazzi and D. Mcdonnell, Populists in power. London: Routledge, 2005, 5-6.

${ }^{6}$ L. Manucci and M. Amsler, 'Where the wind blows: Five Star Movement's populism, direct democracy and ideological flexibility'. Rivista Italiana Di Scienza Politica, 48/1 (2018): 9.

7 T. Pauwels, Populism in Western Europe: Comparing Belgium, Germany and The Netherlands. London: Routledge, 2014, 159.

${ }^{8}$ S. Bowler, D. Denemark, T. Donovan and D. Mcdonnell, 'Right-wing populist party supporters: Dissatisfied but not direct democrats'. European Journal of Political Research, 56/1 (2017): 70-91.

${ }^{9}$ K. Jacobs, A. Akkerman \& A. Zaslove, 'The voice of populist people? Referendum preferences, practices and populist attitudes'. Acta Politica, 53/4 (2018): 517-541.

${ }^{10}$ S. Gherghina, 'How Political Parties Use Referendums: An Analytical Framework', East European Politics and Societies, 33/3 (2019): 677-690.

${ }^{11}$ L. Topaloff, 'The Rise of Referendums: Elite Strategy or Populist Weapon?' Journal of Democracy, 28/3 (2017), $127-140$.

12 M. Qvortrup, 'Demystifying Direct Democracy', Journal of Democracy, 28/3 (2017): 141-152.

13 N. Silagadze and S. Gherghina, 'Referendum Policies across Political Systems', The Political Quarterly, 91/1 (2020): 182-191.

${ }^{14}$ K. Jacobs, The Power Or The People. Direct Democratic and Electoral Reforms in Austria, Belgium and The 
Netherlands. PhD Dissertation. Radboud University Nijmegen, 2011; C. Mudde, Populist radical right parties in Europe. New York: Cambridge University Press, 2007.

${ }^{15}$ K.M. Roberts, 'Populism and democracy in Venezuela under Hugo Chávez', in C. Mudde \& C. R. Kaltwasser (Eds.), Populism in Europe and the Americas Threat or Corrective for Democracy? Cambridge: Cambridge University Press, 2012, 136-159.

${ }^{16} \mathrm{~K}$. Collin, 'Populist and authoritarian referendums: The role of direct democracy in democratic deconsolidation', 2019, Retrieved June 4, 2019, from https://www.brookings.edu/wpcontent/uploads/2019/02/FP_20190226_direct_democracy_collin.pdf

17 R. van Crombrugge, 'Are Referendums Necessarily Populist? Countering the Populist Interpretation of Referendums Through Institutional Design', Representation, 2020 (online first).

${ }^{18}$ K. Weyland, 'Populism: A Political-Strategic Approach', in C. R. Kaltwasser, P. Taggart, P. O. Espejo, \& P. Ostiguy (Eds.), The Oxford Handbook of Populism, Oxford \& New York: Oxford University Press, 53.

${ }^{19}$ S. Gherghina, 'How Political Parties Use Referendums: An Analytical Framework', East European Politics and Societies, 33/3 (2019): 677-690. 